\title{
Acúmulo de silício na parte aérea de cultivares de arroz de terras altas afetado pela aplicação de silicato e carbonato no solo
}

\section{Silicon content in the shoots of upland rice cultivars as affected by the application of silicate and limestone in the soil}

\author{
Munir Mauad ${ }^{1}$; Carlos Alexandre Costa $\mathrm{Crusciol}^{2}$; Adriano Stephan Nascente ${ }^{3 *}$; \\ Hélio Grassi Filho ${ }^{4}$; Juliano Carulli Corrêa ${ }^{5}$
}

\begin{abstract}
Resumo
O silício é o elemento mais absorvido pela planta de arroz com diversos efeitos benéficos como: aumento da tolerância a pragas e doenças, redução da perda de água por transpiração e melhorias na arquitetura foliar tornando as folhas mais eretas, resultando também na melhoria da eficiência fotossintética. Pouco se conhece a respeito da marcha de absorção em plantas de arroz de terra altas. O trabalho teve o objetivo de avaliar o acúmulo de silício em duas cultivares de arroz de terras altas em função da aplicação de silicato e carbonato no solo. $\mathrm{O}$ trabalho foi realizado em casa de vegetação em Latossolo Vermelho distroférrico, utilizando delineamento inteiramente casualizado em esquema fatorial $2 \times 2 \times$ 7, com quatro repetições. Os tratamentos foram constituídos da aplicação de silicato de cálcio e calcário dolomítico em interação com sete épocas de amostragem, realizadas em diferentes estádios fenológicos; utilizando as cultivares de arroz de terras altas Caiapó e Maravilha. Na cultivar Maravilha o acúmulo de Si começa a partir do perfilhamento e alcança seu maior valor no emborrachamento, enquanto que na cultivar Caiapó, ocorre entre o perfilhamento até o estádio de grão leitoso. A cultivar Caiapó foi eficiente em acumular Si na condição em que há o seu fornecimento ao solo. Os órgãos da planta que mais acumularam silício em ambas cultivares de arroz seguiram a seguinte ordem decrescente: colmo+bainha $>$ folhas $>$ panícula.
\end{abstract}

Palavras-chave: Oryza sativa L., estádios fisiológicos, elementos benéficos

\begin{abstract}
Even the element silicon being the most uptake by rice plant, many benefit effect like: increase of pest and disease tolerance, decrease of lost of water by transpiration and better the leaf architecture becoming the leafs more erect, resulting as well at the better photosynthesis efficacy. There is not too much knowledge about the uptake march in upland rice plants. This study aimed to evaluate the content of silicon in two upland rice cultivars by the influence of the application of silicate and limestone at the soil. The experiment was carried in Hapludox soil in a completely randomized experimental design in $2 \times 2 \times 7$ factorial scheme in four replications. The treatments were consisted of calcium silicate fertilizer and limestone in interaction with seven period of physiological stage, using the upland rice cultivars
\end{abstract}

\footnotetext{
1 Eng $^{\mathbf{0}}$ Agr $^{\circ}$, Prof. Dr. da Universidade Federal da Grande Dourados, Faculdade de Ciências Agrárias, Rodovia Dourados, Itahum, Km 12, C P 533, CEP 79804-970, Dourados, MS. E-mail: mauad@ufgd.edu.br

2 Eng ${ }^{\circ}$ Agr $^{\circ}$, Prof. Titular Dr., Universidade Estadual Paulista,UNESP, Faculdade de Ciências Agronômicas, FCA, Dept ${ }^{\circ}$ de Produção Vegetal. Botucatu, São Paulo, SP. Bolsista do CNPq. E-mail: crusciol@fca.unesp.br

3 Eng ${ }^{\circ}$ Agr $^{\circ}$, Pesquisador, Dr. da Embrapa Arroz e Feijão, Santo Antônio de Goiás, Goiás, GO. E-mail: adriano.nascente@embrapa.br

4 Eng $^{\mathrm{o}}$ Agr $^{\mathrm{o}}$, Prof. Titular Dr., Dept ${ }^{\mathrm{o}}$ de Recursos Naturais, Ciência do Solo, UNESP/FCA, Botucatu, São Paulo, SP. E-mail: heliograssi@fca.unesp.br

5 Eng ${ }^{\circ}$ Agr $^{\circ}$, Pesquisador, Dr. da Embrapa Suínos e Aves. Concórdia, SC. E-mail: juliano.correa@embrapa.br

* Autor para correspondência
} 
Caiapó and Maravilha. At the cultivar Maravilha Si accumulation begin from tillering and achieve it better value at the microsporogenesis, while the Caiapó cultivar, occurs between tillering until the mily grain. Caiapó shows efficient Si accumulation when it was supplied to the soil. Plant organs that more accumulated silicon in both upland rice cultivars followed decreased order: stem $>$ leaf $>$ panicle.

Key words: Oryza sativa L., physiologic stage, benefic element

\section{Introdução}

O silício é o elemento mais absorvido pela planta de arroz (KORNDÖRFER; DATNOFF; CORRÊA 1999; TOKURA et al., 2011). No entanto, este elemento pode estar pouco disponível à planta em função do elevado grau de intemperismo dos solos de regiões tropicais, resultado das alterações estruturais e químicas do mineral de argila (BARBOSA FILHO et al., 2001; FAGERIA; BALIGAR; JONES, 2011), assim como dos elevados teores de sesquióxidos de Al e Fe (MALAVOLTA, 2006) que são responsáveis pela adsorção de Si disponível para as plantas (TAIZ; ZEIGER, 2009) e também da ausência de adubação silicatada, uma vez que a extração do elemento pelas culturas, não é resposta pela aplicação de fertilizantes (MAUAD; CRUSCIOL; GRASSI FILHO, 2011). Essas condições são comuns nos solos do cerrado brasileiro, que representa cerca de $60 \%$ da área cultivada com arroz no ecossistema de terras altas (CONAB, 2011).

O silício nas plantas de arroz é depositado na parede celular da epiderme das folhas, colmos e casca do grão, formando uma dupla camada de sílica-cutícula e sílica-celulose (RAVEN, 2003), que reduz a perda de água por transpiração (BARBOSA FILHO et al., 2001), aumenta a tolerância a pragas (GOUSSAIN et al., 2002), doenças (BERNI; PRABHU, 2003; PRABHU; SANTOS; DIDONET, 2007; REZENDE et al., 2009) e a resistência ao acamamento, tornando as plantas mais eretas, resultando também na melhoria da eficiência fotossintética (GAO et al. 2004; ÁVILA et al., 2010) em função da menor abertura do angulo foliar, o que permite uma maior capitação da energia luminosa. Portanto, os efeitos do silício em plantas de arroz confere melhores condições morfofisiológicas à planta, especialmente quando estas estão submetidas a estresse biótico ou abiótico (MA et al., 2004, MA et al., 2006).

A marcha de absorção de um nutriente fornece informações sobre a exigência nutricional das plantas em seus diferentes estádios fenológicos, sinalizando as épocas mais propícias à adição dos nutrientes (FALQUETO et al., 2009). Entretanto, a quantidade e a proporcionalidade dos nutrientes absorvidos pelas plantas são funções de características intrínsecas do vegetal, como, também, dos fatores externos que condicionam o processo (FAGERIA; BALIGAR; JONES, 2011). Numa espécie, a capacidade em retirar os nutrientes do solo e as quantidades requeridas variam, não só com a cultivar, mas também com o grau de competição existente (MAUAD; CRUSCIOL; GRASSI FILHO, 2011).

Entre as gramíneas, o arroz possui a maior habilidade de absorção de silício (TAMAI; MA, 2003, TOKURA et al., 2011), em função da maior densidade de transportadores no sistema radicular em relação a outras espécies (MITANI; MA, 2005; MA et al., 2006). O transporte de silício é mediado por proteínas específicas (transportadores), localizadas nas células da exoderme e da endoderme (MITAMI; MA, 2005) sendo este realizado de forma ativa (MA, 2004; MA et al., 2006). Segundo Korndörfer, Pereira e Nolla (2004a) as principais formas de Si presentes no solo são: $\mathrm{Si}$ solúvel constituída primordialmente do ácido monosilícico ( $\mathrm{H} \mathrm{SiO})$, Si polimerizado de difícil aproveitamento ${ }^{4}$ pelas plantas, Si adsorvido ou precipitado com óxidos de $\mathrm{Fe}, \mathrm{Al}$ e $\mathrm{Mn}$, e os minerais silicatados (cristalinos ou amorfos), praticamente não disponíveis.

As plantas absorvem o silício da solução do solo na forma iônica e como ácido silícico $\left(\mathrm{H}_{4} \mathrm{SiO}_{4}\right)$, sendo essa a forma mais facilmente aproveitada 
(FAGERIA; BALIGAR; JONES, 2011). A capacidade de absorção de silício ocorre de forma distinta entre e interespécies vegetais, podendo a concentração de silício nas plantas variar entre 10 a $100 \mathrm{~g} \mathrm{~kg}^{-1}$ matéria seca (MAUAD; CRUSCIOL; GRASSI FILHO, 2011). Cultivares de arroz diferem na quantidade de silício absorvido, respondendo de modo diferente à aplicação do elemento (DEREN et al., 1994). Genótipos de arroz do grupo Japônica apresentam concentração de silício de 50 a 100\% mais alta que genótipos do grupo Índica (WINSLOW, 1992; SANTOS; STONE; VIEIRA, 2006).

Apesar da importância do silício para a agricultura e em especial para as culturas acumuladoras como $\mathrm{o}$ arroz, estudos relacionados à marcha de absorção desse elemento para cultivares de terras altas são escassos até o momento (MAUAD; CRUSCIOL; GRASSI FILHO, 2011). Diante disso, o trabalho teve por objetivo avaliar o acúmulo de silício em duas cultivares de arroz de terras altas em função da aplicação de silicato e carbonato no solo.

\section{Material e Métodos}

$\mathrm{O}$ experimento foi desenvolvido em casa de vegetação, sob temperatura média de $28^{\circ} \mathrm{C}$ no Departamento de Produção Vegetal da Faculdade de Ciências Agronômicas, FCA/UNESP, Campus de Botucatu, $122^{\circ} 51^{\prime} \mathrm{S}$, longitude $48^{\circ} 26^{\prime} \mathrm{W}$ e altitude $740 \mathrm{~m}$, durante os meses de janeiro a março de 2004.

O solo utilizado foi coletado da camada superficial $(0-20 \mathrm{~cm})$, provenientes de um Latossolo Vermelho distroférrico, de textura média (EMBRAPA, 2006). Antes da instalação do experimento, foi coletada e analisada uma amostra composta do solo, sendo as análises de rotina determinadas conforme Raij et al. (2001) e o silício segundo Korndörfer, Pereira e Camargo (2004b), obtendo-se as seguintes características: $\mathrm{pH}\left(\mathrm{CaCl}_{2}\right)=4,3$; $\mathrm{M} . \mathrm{O}=29,1 \mathrm{~g} \mathrm{~kg}^{-}$ 1; P-resina $=2,5 \mathrm{mg} \mathrm{dm}^{-3}$; $\mathrm{Si}\left(\mathrm{CaCl}_{2}\right)=3,4 \mathrm{mg} \mathrm{dm}^{-}$ 3; 1,4, 13, 0,73 e $63 \mathrm{mmol}_{\mathrm{c}} \mathrm{dm}^{-3}$ para $\mathrm{K}, \mathrm{Ca}, \mathrm{Mg}$ e $\mathrm{H}+\mathrm{Al}$ e $\mathrm{V}=16 \%$. A terra coletada, após secagem ao ar, foi passada em peneira de $4 \mathrm{~mm}$, para separação de torrões, raízes e palha, acondicionando-a nas unidades experimentais, que foram constituídas por vasos de polietileno com capacidade para $10 \mathrm{dm}^{-3}$ de solo.

O delineamento experimental utilizado foi inteiramente casualizado em esquema fatorial $2 \times 2$ x 7 com quatro repetições, totalizando 112 unidades experimentais. Os tratamentos foram constituídos por duas cultivares (Caiapó e Maravilha), ausência e presença de $\mathrm{Si}$ (0 e $373 \mathrm{~kg} \mathrm{ha}^{-1}$ de Si) e sete épocas de desenvolvimento (início do perfilhamento $\mathrm{V} 1$, perfilhamento máximo - V2, diferenciação do primórdio da panícula - R1, emborrachamento - R2, antese - M1, grão leitoso - M2 e maturação fisiológica - M3).

O Si foi fornecido via silicato de cálcio na dose equivalente a $3,48 \mathrm{tha}^{-1}$. No tratamento sem Si foi feita a aplicação de calcário dolomítico equivalente a 3,40 $\mathrm{tha}^{-1}$. Estas operações foram realizadas 30 dias antes da semeadura, visando elevar a saturação por bases a 60\% (RAIJ et al., 1996). As sete épocas de amostragem, foram pré-definidas em função dos estádios fenológicos do arroz (SANTOS; STONES; VIEIRA, 2006).

O calcário dolomítico apresentou PRNT de 93 $\%$, $\mathrm{CaO} 39 \%$ e $\mathrm{MgO} 13 \%$. O silicato de cálcio apresentava PRNT de 91\%, $\mathrm{CaO} 42 \%$ e $\mathrm{MgO} 12 \%$, além de $23 \%$ de $\mathrm{SiO}_{2}$. A adubação de semeadura com N, P, K e micro, constou das seguintes doses: $150 \mathrm{mg} \mathrm{dm}^{-3}$ de $\mathrm{P}$ (superfosfato simples), $100 \mathrm{mg}$ $\mathrm{dm}^{-3}$ de $\mathrm{K}$ (cloreto de potássio), $50 \mathrm{mg} \mathrm{dm}^{-3}$ de $\mathrm{N}$ (uréia) e $1 \mathrm{~g} \mathrm{dm}^{-3}$ de FTE Br-12. Estes nutrientes foram aplicados seguindo a proposta realizada por Büll et al. (2004) para adubação em vaso. Aos 30 dias após a emergência foi realizada adubação de cobertura com nitrogênio e potássio na dose de 50 $\mathrm{mg} \mathrm{dm}{ }^{-3}$ de $\mathrm{N}$ e $50 \mathrm{mg} \mathrm{dm}^{-3}$ de K.

A semeadura foi realizada no dia 14/01/04, utilizando 15 sementes por vaso. Aos sete (7) dias após a semeadura, quando $50 \%$ das plântulas de cada unidade experimental apresentavam o 
coleóptilo acima do nível do solo, considerou-se a data de emergência (21/01/04). Realizou-se um desbaste aos sete dias após a emergência (DAE), deixando-se 3 plantas por vasos, exceção aos vasos da primeira coleta que ficaram com 10 plantas, de modo a ter material vegetal suficiente para as análises propostas. A cultivar Caiapó alcançou estádios pré-estabelecidos (V1, V2, R1, R2, M1, M2 e M3) aos 22, 50, 61, 85, 95102 e 131 dias após a emergência (DAE) e a cultivar Maravilha aos 22, 55, 77, 89, 100107 e 148 DAE.

O manejo da irrigação foi feito de forma a manter o teor de umidade do solo dos vasos na capacidade de campo. No início do experimento foi feito a determinação do peso do vaso, com o solo seco (em estufa) e na capacidade de retenção da água do solo (CRUSCIOL et al., 2006). Durante a condução do experimento com o auxilio de uma balança eletrônica, pesavam-se os vasos fazendo a reposição da água perdida através da evapotranspiração (CRUSCIOL et al., 2006).

As variáveis analisadas foram: massa de matéria seca e acúmulo de silício na parte aérea da planta de arroz. Para estas avaliações coletou-se três plantas por de cada vaso, sendo que a parte aérea foi separada em folha, colmo + bainha e panícula, de acordo com as respectivas épocas de coleta. $\mathrm{O}$ material vegetal foi acondicionado em sacos de papel e colocados em estufa de circulação de ar forçada na temperatura de $65^{\circ} \mathrm{C}$, até a obtenção da massa constante. Após secas essas amostras foram pesadas obtendo-se assim a matéria seca da parte aérea. Para a análise de silício o material foi triturado em moinho tipo Willey e após homogeneização da amostra foi retirada e pesada uma alíquota de 0,1 g para análise, seguindo metodologia proposta por Korndörfer, Pereira e Camargo (2004b).

Os dados de matéria seca e acúmulo de silício na parte aérea foram submetidos à análise de variância e, foi montada uma tabela para apresentação da significância dos resultados e analise de regressão adotando-se o modelo sigmoidal, e verificando-se o nível de significância pelo teste $\mathrm{F}$ à nível de $1 \%$ e 5\%. Para determinação das análises de regressão adotou-se o programa Sigmaplot 10.0. Assim, os resultados de matéria seca e de silício durante o ciclo dos cultivares de arroz Caiapó e Maravilha foram ajustados conforme a equação 1 :

$$
\mathrm{Y}=\mathrm{A} /\left(1+\operatorname{EXP}\left(-\left(\mathrm{X}-\mathrm{X}_{0}\right) / \mathrm{B}\right)\right)(\text { equação } 1)
$$

em que: Y é a massa de matéria seca (g planta $\left.{ }^{-1}\right)$ ou a quantidade de silício acumulado da parte aérea da planta de arroz em mg planta $^{-1}$; e $\mathrm{X}=$ dias após emergência.

Os parâmetros $\mathrm{A}, \mathrm{X}_{0}$ e $\mathrm{B}$ foram estimados pelo programa SigmaPlot. As equações foram obtidas para descrever a variação, no tempo, da massa de matéria seca e da quantidade acumulada de silício na parte aérea das plantas de arroz até a época de colheita. Para comparação entre o carbonato e o silicato, na mesma dose, optou-se por utilizar o desvio padrão da média.

\section{Resultados e Discussão}

Houve efeito significativo da interação tripla para todos os fatores avaliados (Tabela 1). Assim, a aplicação de silicato de cálcio e calcário dolomítico proporcionou crescimento distinto, tanto para a cultivar Maravilha quanto para a Caiapó, demonstrado pela matéria seca (Figura 1). Com a aplicação de silicato de cálcio a cultivar Maravilha apresentou maior produção de matéria seca da parte aérea nos estádios de antese (M1) e grão leitoso (M2) em relação ao tratamento com calcário. $\mathrm{Na}$ cultivar Caiapó nos tratamentos com aplicação de silicato verificou-se maior produção de matéria seca na fase de maturação fisiológica (M3), sendo que nos estádios R1 e M1 a calagem apresenta-se como o tratamento mais eficiente, resultados justificados pelos valores de desvio padrão. 
Tabela 1. Análise de variância da massa de matéria seca (MS) e acúmulo de silício (Ac) na parte aérea plantas de arroz de terras altas em função da cultivar, presença e ausência de Si e época de avaliação.

\begin{tabular}{|c|c|c|c|c|c|c|c|c|}
\hline \multirow{2}{*}{ Fontes de variação } & MS_T & MS_CB & MS_F & MS_P & Ac_T & Ac_CB & Ac_F & Ac_P \\
\hline & \multicolumn{8}{|c|}{ ANAVA (Probabilidade do teste F) } \\
\hline Cultivar (C) & $<, 001$ & $<, 001$ & $<, 001$ & $<, 001$ & 0,002 & $<, 001$ & $<, 001$ & 0,170 \\
\hline Dose de Silício (Si) & $<, 001$ & 0,617 & $<, 001$ & 0,003 & $<, 001$ & $<, 001$ & $<, 001$ & $<, 001$ \\
\hline Época avaliação (E) & $<, 001$ & $<, 001$ & $<, 001$ & $<, 001$ & $<, 001$ & $<, 001$ & $<, 001$ & $<, 001$ \\
\hline $\mathrm{C} \times \mathrm{Si}$ & $<, 001$ & 0,672 & $<, 001$ & 0,266 & 0,085 & $<, 001$ & 0,003 & 0,019 \\
\hline $\mathrm{C} \times \mathrm{E}$ & $<, 001$ & $<, 001$ & $<, 001$ & $<, 001$ & $<, 001$ & $<, 001$ & $<, 001$ & $<, 001$ \\
\hline Si $x \mathrm{E}$ & $<, 001$ & $<, 001$ & $<, 001$ & $<, 001$ & $<, 001$ & $<, 001$ & $<, 001$ & $<, 001$ \\
\hline $\mathrm{C} \times \mathrm{Si} \times \mathrm{E}$ & $<, 001$ & $<, 001$ & $<, 001$ & 0,019 & $<, 001$ & $<, 001$ & $<, 001$ & $<0,001$ \\
\hline $\mathrm{CV}$ & 4,92 & 5,55 & 4,71 & 13,49 & 5,89 & 7,82 & 7,91 & 20,54 \\
\hline
\end{tabular}

MS_T: matéria seca total; MS_CB: matéria seca de colmo + bainha; MS_F: matéria seca de folhas MS_P: matéria seca de panícula; AC_T: acúmulo de silício total; AC_CB: acúmulo de silício de colmo + bainha; AC_F: acúmulo de silício na folha; AC_P: acúmulo de silício na panícula.

Fonte: Elaboração dos autores.

Os resultados de matéria seca na cultura do arroz em função da adubação silicatada são divergentes. Mauad et al. (2003), trabalhando com a cultivar IAC 202, nas doses de 0, 186, 374 e $560 \mathrm{~kg} \mathrm{ha}^{-1}$ de $\mathrm{Si}$, não verificaram efeito do silício na matéria seca da parte aérea, Ávila et al. (2010) com a cultivar BRSMG Conai também não observaram efeito da adubação silicatada (0 e $50 \mathrm{mgL}^{-1}$ de silício) no aumento da matéria seca da parte aérea do arroz e Mauad, Crusciol e Grassi Filho (2011) utilizando doses de 0 e $350 \mathrm{~kg} \mathrm{ha}^{-1}$ de silício não obtiveram aumentos significativos de massa de matéria seca da parte aérea do arroz. Por outro lado, Faria Junior et al. (2009) avaliando cultivares de arroz (Conai e Curinga) com aumento de doses de $\mathrm{Si}$, verificaram aumento de matéria seca da raiz do arroz. Sávio et al. (2011) observaram que nas espécies Brachiaria brizantha e Panicum máximum houve efeito positivo do silício na produção de massa seca no $2^{\circ}$ e $3^{\circ}$ corte. Nesse trabalho, tanto a aplicação de silicato de cálcio quanto à calagem proporcionaram a mesma quantidade de matéria seca da parte aérea no final do ciclo para a cultivar Maravilha, enquanto que para a Caiapó pode-se verificar maior produção de matéria seca em razão da aplicação do silicato de cálcio, resultado justificado pela diferença de desvio padrão entre os tratamentos. 
Figura 1. Matéria seca da parte aérea nas cultivares de arroz Maravilha e Caiapó. Barras verticais representam o desvio padrão. DAE - dias após a emergência.
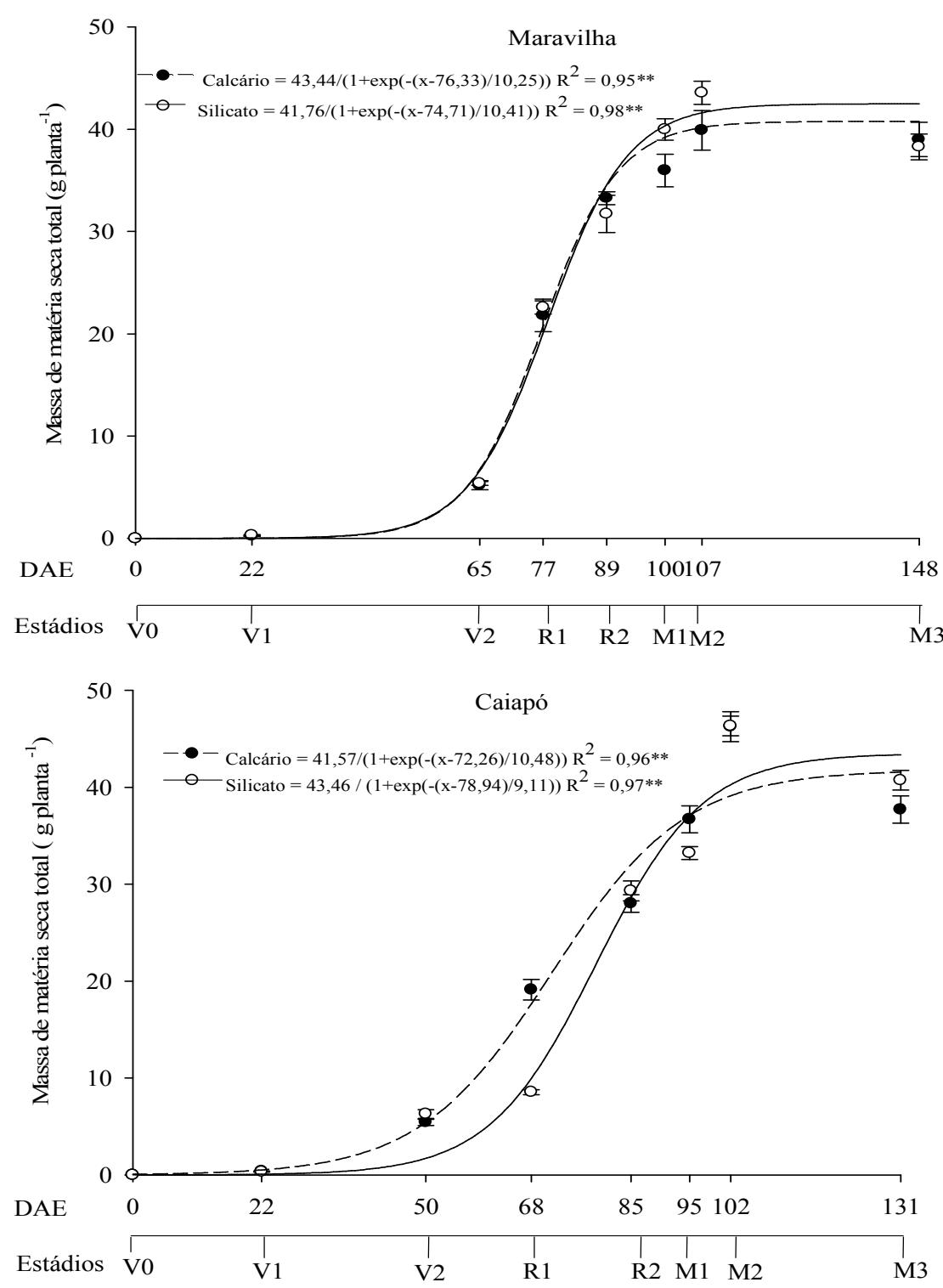

Fonte: Elaboração dos autores.

O acúmulo de silício na parte aérea (Figura 2) foi distinto entre as cultivares. A cultivar Maravilha absorveu silício de forma mais rápida, a partir do perfilhamento (50 DAE) e atingiu o máximo acúmulo $\left(23,97 \mathrm{mg}\right.$ planta $\left.^{-1}\right)$ no estádio de emborrachamento (R2), quando utilizou-se silicato de cálcio (Figura 2). Nos tratamentos com calcário dolomítico, a absorção ocorreu de forma mais gradativa com o início do perfilhamento (V1) e, alcançando o maior valor acumulado $\left(21,45 \mathrm{mg}\right.$ planta $\left.^{-1}\right)$ no estádio de maturação fisiológica do grão (M3), ou seja no final do ciclo.

Com a aplicação de silicato de cálcio a cultivar Maravilha absorveu silício de forma rápida, o que pode conferir às plantas os efeitos benéficos deste elemento, tais como, reduzir a perda de água por 
transpiração (BARBOSA FILHO et al., 2001; FAGERIA; BALIGAR; JONES, 2011) aumentar a tolerância a pragas (GOUSSAIN et al., 2002), doenças (BERNI; PRABHU, 2003; PRABHU; SANTOS; DIDONET, 2007; BUCK et al., 2008; REZENDE et al., 2009). Além da maior resistência ao acamamento, tornando as plantas mais eretas, resultando também na melhoria da eficiência fotossintética (GAO et al., 2004; TOKURA et al., 2011), já nos primeiros estádios fenológicos da planta em relação a aplicação de calagem.

Figura 2. Acúmulo total de silício da parte aérea nas cultivares de arroz Maravilha e Caiapó. Barras verticais representam o desvio padrão. DAE - dias após a emergência.
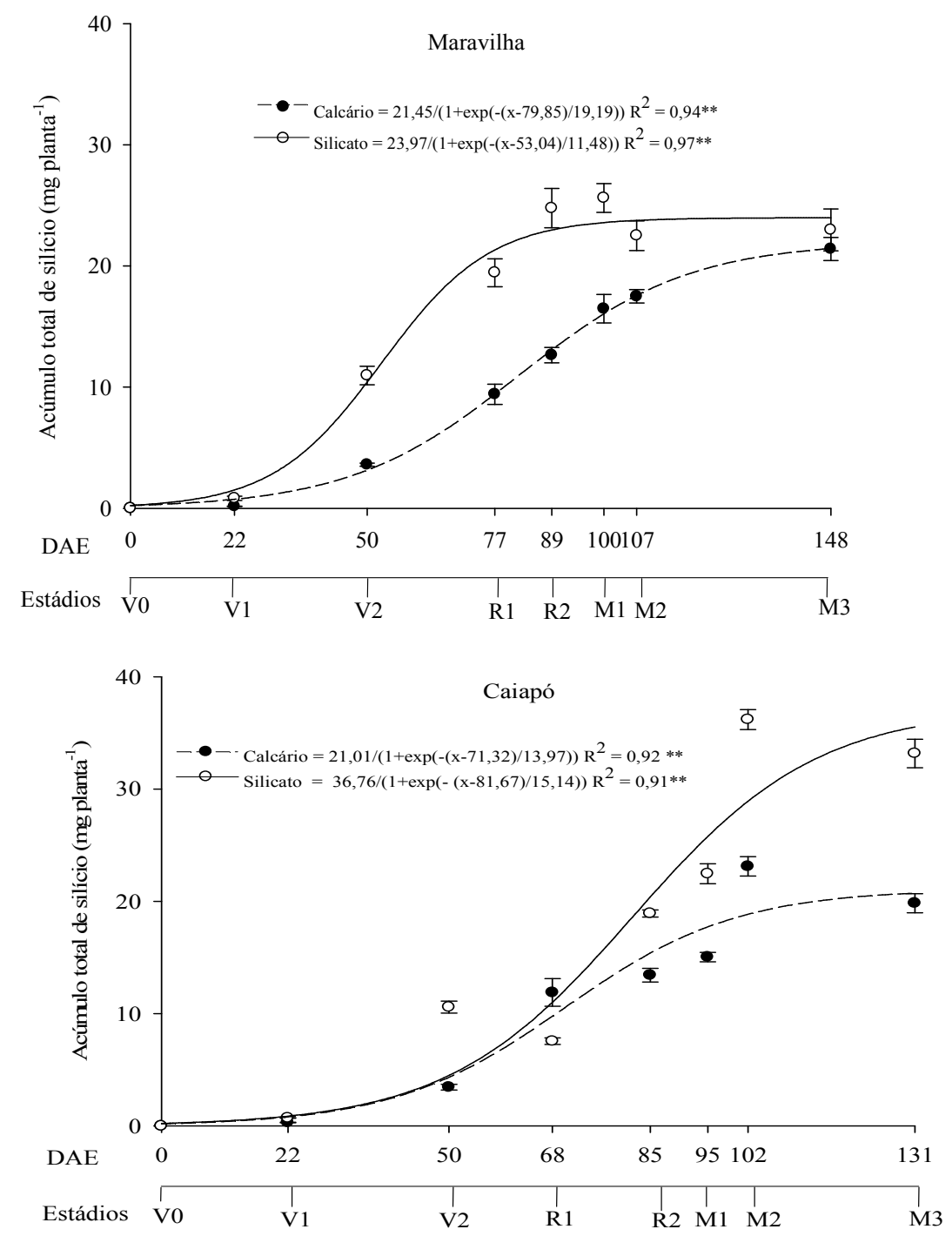

Fonte: Elaboração dos autores.

O maior acúmulo de silício na cultivar Caiapó foi observado no tratamento com silicato de cálcio (Figura 2). A maior velocidade de absorção ocorreu entre o final do perfilhamento (V2) e o estádio de grão leitoso (M2), sendo que o valor máximo acumulado foi de $36,72 \mathrm{mg}_{\text {planta }}{ }^{-1}$. No tratamento com o calcário dolomítico verificou-se menor acúmulo de silício, atingindo o máximo valor 
(21,01 mg planta-1 $)$ no estádio de grão leitoso (M2). A capacidade de absorção de silício é o principal determinante da concentração desse elemento nas células podendo a absorção ser favorecida pela transpiração (MOTOMURA; MITA; SUZUKI, 2002) ou por estimulo a proteção contra estresses abióticos ou bióticos (CURRIE, PERRY, 2007). Vale ressaltar que a planta de arroz possuir maior habilidade de absorção de silício (TAMAI; MA, 2003; MA et al., 2006; RAMOS; KORNDORFER; NOLLA, 2008), em função da maior densidade de transportadores no sistema radicular em relação a outras espécies (MITAMI; MA, 2005), localizados na membrana plasmática das células da endoderme e da exoderme (MA et al., 2006), sendo o transporte realizado de forma ativa (MA et al., 2004 ; MA et al., 2006). Portanto, o maior acúmulo de Si na parte aérea da Caiapó, no tratamento com silicato de cálcio, pode ser justificado pela eficiência dos seus carregadores específicos de Si na raiz. Segundo Ma et al. (2007) diferenças genotípicas na acumulação de Si em plantas de arroz podem estar relacionadas na diferença da expressão de genes transportadores de Si na raízes. Estudos realizados por Ma, Miyake e Nishimura (1989) mostraram que a fase reprodutiva é onde ocorre a maior absorção de silício pelas plantas de arroz, e que segundo Yamaji e Ma (2007) nesta fase ocorre a maior expressão do gene Lsi 1 que está relacionado a absorção de silício em plantas de arroz.

Essa mesma afirmação permite predizer que os carregadores de Si da cultivar Maravilha não são tão eficientes e/ou podem estar em menor número, pois houve o mesmo acúmulo desse elemento no final de seu ciclo, em razão do fornecimento e da ausência da aplicação do Si no solo. A maior velocidade de absorção do Si ocorre nos primeiros estádios fenológicos da Maravilha e, pode estar ligada ao mecanismo passivo de absorção (Van der VORM, 1980), em função do fluxo transpiratório (TAIZ; ZEIGER, 2009), uma vez que há maior disponibilidade desse elemento quando foi utilizado silicato de cálcio. Segundo Winslow (1992) e Santos, Stone e Vieira (2006) genótipos de arroz do grupo Japônica apresentam concentração de $\mathrm{Si}$ de 50 a $100 \%$ mais alta que genótipos do grupo Índica, e cultivares tradicionais apresentam maior eficiência na absorção desse elemento.

A quantidade e a proporcionalidade dos elementos absorvidos pelas plantas são funções de características intrínsecas do vegetal, como, também, dos fatores externos que condicionam o processo (FAGERIA; BALIGAR; JONES, 2011). Numa espécie, as capacidades em retirar os elementos do solo e a demanda requerida variam em função de vários fatores, dentre eles a cultivar (FARIA JUNIOR et al., 2009). Segundo Mitami e Ma (2005) o acúmulo de Si na planta pode ser influenciado pela transpiração, pelo período e a taxa de crescimento entre outros, porém a habilidade do sistema radicular em absorver Si é o que determina a quantidade acumulada.

Assim, o acúmulo de Si entre as cultivares em função dos tratamentos de silicato e calagem, pode estar relacionada às características genéticas de cada material, uma vez que as cultivares utilizadas são de grupos diferentes, a Maravilha: pertencente ao grupo moderno (plantas de porte baixo, folhas curtas, eretas, colmos fortes, alto perfilhamento e respondem, sem acamar, à melhoria da fertilidade do solo e a adubação nitrogenada) enquanto a cultivar Caiapó: pertencente ao grupo tradicional (plantas de porte alto, folhas longas e decumbentes, baixa capacidade de perfilhamento, acamamento em solos férteis ou quando adubados com doses elevadas de nitrogênio (SANTOS; STONE; VIEIRA, 2006).

Talvez, a maior habilidade na absorção de Si pelo arroz em relação a outras gramíneas como o milho, aveia, trigo, cevada, sorgo e triticale (TAMAI; MA, 2003), ocorre em função da presença dos transportadores de $\mathrm{Si}$, principalmente quando há menor disponibilidade desse elemento no solo. É possível ainda, que exista diferença intraespecífica para a absorção de $\mathrm{Si}$, com relação a quantidade e a especificidade desses transportadores entre as cultivares de arroz. Como no caso da Caiapó e da Maravilha, as quais apresentaram comportamento 
diferenciado quanto ao acúmulo de Si na parte aérea (Figura 2). Vale lembrar que esses transportadores são proteínas como a SIT1 localizada nas células da endoderme que faz o transporte da solução externa para células cortical, e a proteína SIT2 localizada nas células da exoderme que descarrega o Si das células corticais no xilema (MITAMI; MA, 2005; MA et al., 2006).

A parte da planta que mais acumulou $\mathrm{Si}$ foi o colmo + bainha, seguida das folhas e da panícula, em ambas cultivares (Figuras 3 e 4). Esse padrão de acúmulo de silício está relacionado ao fato do Si ser depositado em locais onde é necessário uma maior rigidez (OLIVEIRA et al., 2010). Nota-se, nas Figuras 3 e 2, que para a cultivar Maravilha o acúmulo total de $\mathrm{Si}$ na planta apresentou valores próximos em função dos tratamentos, o que pode indicar maior eficiência desta cultivar na absorção de Si em baixa disponibilidade como no solo deste estudo $\left(\mathrm{Si}=3,4 \mathrm{mg} \mathrm{dm}^{-3}\right.$ ), enquanto na cultivar Caiapó (Figuras 4 e 2) os valores para silício total foram maiores na presença de silicato em relação ao calcário.

Figura 3. Marcha de absorção de silício em função da aplicação de silicato e calcário na cultivar Maravilha. DAE dias após a emergência.
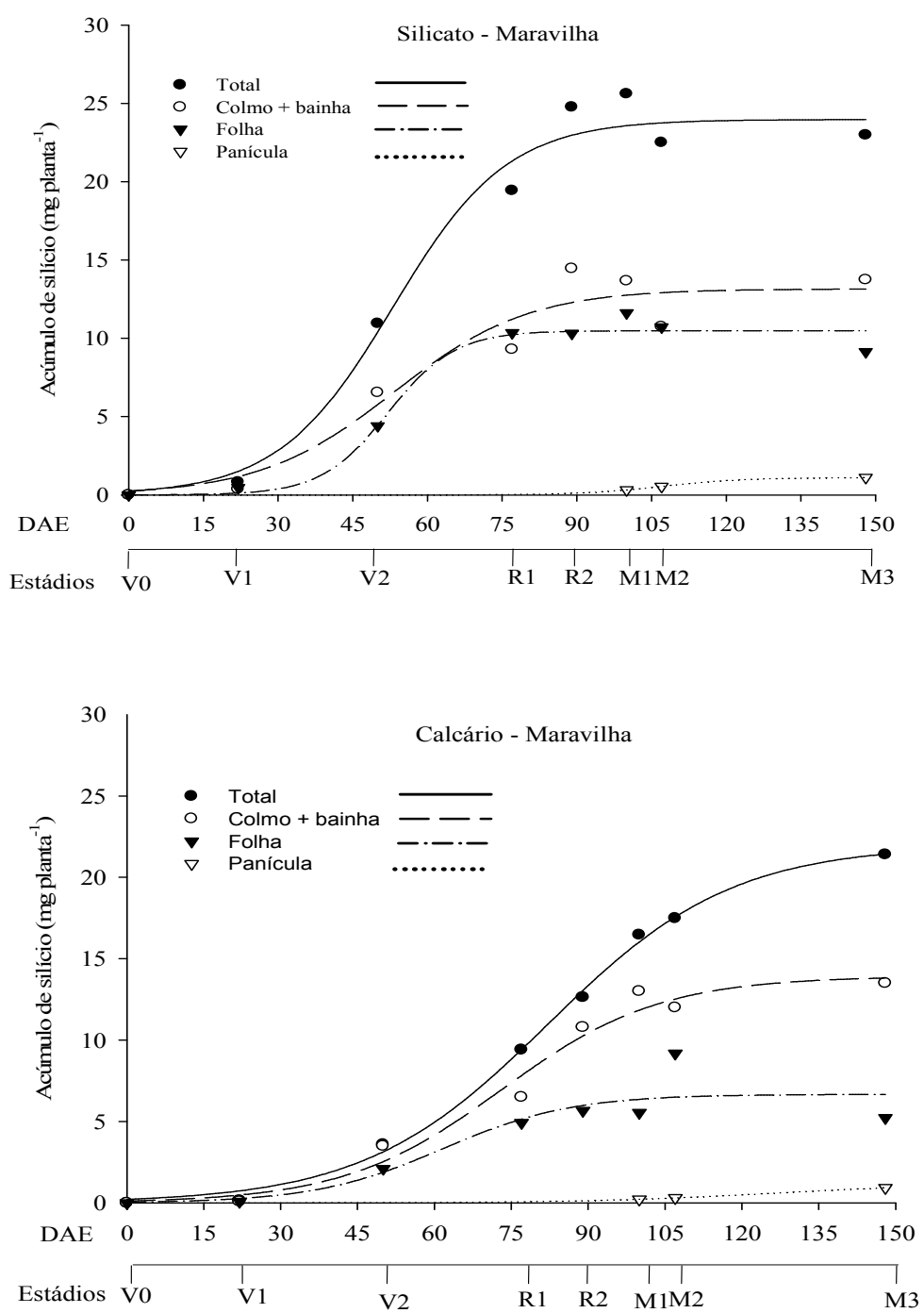

Fonte: Elaboração dos autores. 
Figura 4. Marcha de absorção de silício em função da aplicação de silicato e calcário na cultivar Caiapó. DAE - dias após a emergência.
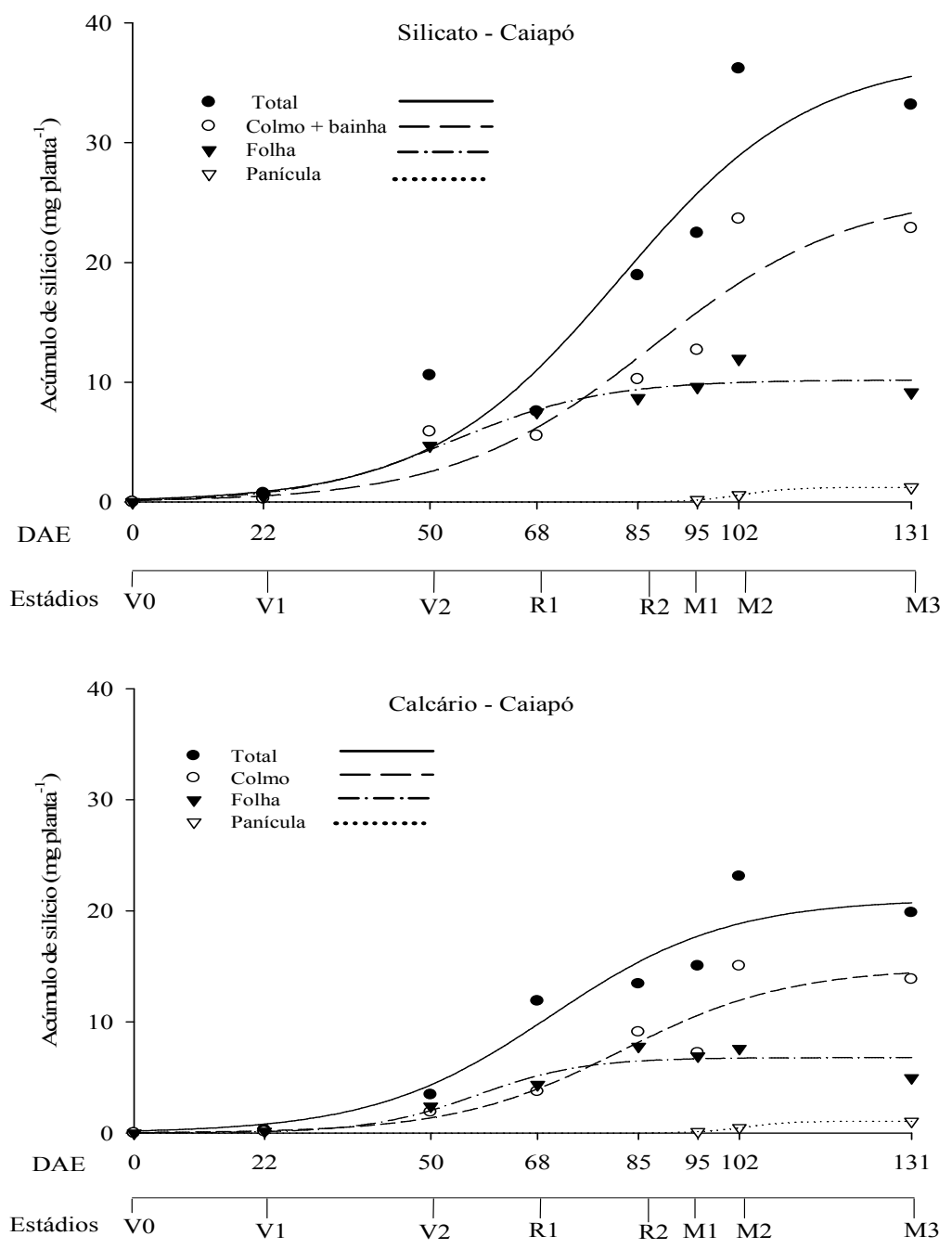

Fonte: Elaboração dos autores.

\section{Conclusões}

$\mathrm{Na}$ cultivar Maravilha o acúmulo de Si começa a partir do perfilhamento e alcança seu maior valor no emborrachamento, enquanto na cultivar Caiapó, ocorre entre o perfilhamento até o estádio de grão leitoso.

A cultivar Caiapó mostra-se eficiente em acumular Si na condição em que há o seu fornecimento ao solo. mais acumularam silício seguiram a seguinte ordem decrescente: colmo+bainha $>$ folhas $>$ panícula, em ambas cultivares de arroz de terras altas.

\section{Agradecimentos}

A FAPESP pelo financiamento da pesquisa, e ao CNPq pela concessão de bolsa de produtividade em pesquisa ao segundo autor.

Os órgãos da planta de ambas cultivares que 


\section{Referências}

ÁVILA, F. W.; BALIZA, D. P.; FAQUIN, V.; ARAÚJO, J. L.; RAMOS, S. J. Interação entre silício e nitrogênio em arroz cultivado sob solução nutritiva. Revista Ciência Agronômica, Fortaleza, v. 41, n. 2, p. 184-190, 2010.

BARBOSA FILHO, M. P.; SNYDER, G. H.; FAGERIA, N. K.; DATNOFF, L. E.; SILVA, O. F. Silicato de cálcio como fonte de silício para o arroz de sequeiro. Revista Brasileira de Ciência do Solo, Viçosa, v. 25, n. 2, p. 32530, 2001.

BERNI, R. F.; PRABHU, A. S. Eficiência relativa de fontes de silício no controle de brusone nas folhas em arroz. Pesquisa Agropecuária Brasileira, Brasília, v. 38, n. 2, p. 195-201, 2003.

BUCK, G. B.; KORNDÖRFER, G. H.; NOLLA, A.; COELHO, L. Potassium silicate as foliar spray and rice blast control. Journal of Plant Nutrition, New York, v. 31, n. 2, p. 231-237, 2008.

BÜLL, L. T.; COSTA, M. C. G.; NOVELlO, A.; FERNANDES, D. M.; BOAS, R. L. V. Doses and forms of application of phosphorus in vernalized garlic. Scientia Agricola, Piracicaba, v. 61, n. 5, p. 516-521, 2004.

COMPANHIA NACIONAL DE ABASTECIMENTO CONAB. Levantamento da safra. 2011. Disponível em: $<\mathrm{http}: / /$ www.conab.gov.br>. Acesso em: 24 fev. 2012.

CRUSCIOL, C. A. C.; SORATTO, R. P.; ARF, O.; MATEUS, G. P. Yield of upland rice cultivars in rainfed and sprinkler-irrigated systems in the Cerrado region of Brazil. Australian Journal of Experimental Agriculture, Collingwood, v. 46, n. 11, p. 1515-1520, 2006.

CURRIE, H. A.; PRERY, C. C. Silica in plant: biological, biochemical and chemical studies. Annals of Botany, Oxford, v. 100, n. 7, p. 1383-1389, 2007.

DEREN, C. W.; DATNOFF, L. E.; SNYDER, G. H.; MARTIN, F. G. Silicon concentration, disease response, and yield components of rice genotypes grown on flooded organic Histosols. Crop Science, Madison, v. 34, n. 3, p. 733-37, 1994.

EMPRESA BRASILEIRA DE PESQUISA AGROPECUÁRIA - EMBRAPA. Centro Nacional de Pesquisa de Solos. Sistema brasileiro de classificação de solos. 2. ed. Rio de Janeiro: Embrapa Solos, 2006. 306 p.

FAGERIA, N. K,; BALIGAR, V. C.; JONES, C. A. Growth and mineral nutrition of field crops. Boca Raton: CRC Press, 2011. 640 p.

FALQUETO, A. R.; CASSOL, D.; MAGALHÃES JÚNIOR, A. M.; OLIVEIRA, A. C.; BACARIN, M. A. Partição de assimilados em cultivares de arroz diferindo no potencial de produtividade de grãos. Bragantia, Campinas, v. 68, n. 3, p. 453-461, 2009.

FARIA JUNIOR, L. A. de; CARVALHO, J. G. de; PINHO, P. J. de; BASTOS, A. R. R.; FERREIRA, E. V. Produção de matéria seca, teor e acúmulo de silício em cultivares de arroz sob doses de silício. Ciência e Agrotecnologia, Lavras, v. 33, n. 4, p. 1034-1040, 2009.

GAO, X.; ZOU, C.; WANG, L.; ZHANG, F. Silicon improves water use efficiency in Maize plants. Journal of Plant Nutrition, New York, v. 27, n. 8, p. 1457-1470, 2004.

GOUSSAIN, M. M.; MORAES, J. C.; CARVALHO, J. G.; NOGUEIRA, N. L.; ROSSIN, M. Efeito da aplicação de silício em plantas de milho no desenvolvimento biológico da lagarta do cartucho Spodoptera frugiperda (J.E. Smith) (Lepdoptera: Noctuidae). Neotropical Entomology, Londrina, v. 31, n. 2, p. 305-310, 2002.

KORNDÖRFER, G. H.; PEREIRA, H. S.; CAMARGO, M. S. Análise de silício: solo, planta e fertilizantes. Uberlândia: Universidade Federal de Uberlândia, 2004 b. 34 p. (Boletim técnico, 2).

KORNDÖRFER, G. H.; PEREIRA, H. S.; NOLLA, A. Análise de silício: solo, planta e fertilizante. Uberlândia: Universidade Federal de Uberlândia, 2004a. 24 p. (Boletim técnico, 3).

KORNDÖRFER, G. H.; DATNOFF, L. E.; CORREAA, G. F. Influence of silicon on grain discoloration and upland rice growth in four Savanna soils of Brazil. Journal of Plant Nutrition, New York, v. 22, n. 1, p. 93-102, 1999.

MA, J.; NISHIMRA, K.; TAKAHASHI, E. Effect of silicon on the growth of rice plant at different growth stages. Soil Science and Plant Nutrition, Tokyo, v. 35, n. 3, p. 347-356, 1989.

MA, J. F. Role of silicon in enhancing the resistance of plants to biotic and abiotic stresses. Soil Science and Plant Nutrition, Tokyo, v. 50, n. 1, p. 11-18, 2004.

MA, J. F.; MITANI, N.; NAGAO, S.; KONISHI, S.; TAMAI, K.; IWASHITA, T.; YANO, M. Characterization of the silicon uptake and molecular mapping of the silicon transporter gene in rice. Plant Physiology, Waterbury, v. 136, n. 2, p. 3284-3289, 2004.

MA, J. F.; TAMAI, K.; YAMAJI, N.; MITANI, N.; KONISHI, S.; KATSUHARA, M.; ISHIGURO, M.; MURATA, Y.; YANO, M. Silicon transporter in rice. Nature, London, v. 440, n. 7084, p. 688-691, 2006.

MA, J. F.; YAMAJI, N.; MITANI, N.; TAMAI, K.; KONISHI, S.; FUJIWARA, T.; KATSUHARA, M.; YANO, M. An efflux transporter of silicon in rice. Nature, London, v. 448, n. 7150, p. 209-212, 2007. 
MALAVOLTA, E. Manual de nutrição mineral de plantas. Piracicaba: Agronômica Ceres, 2006. 638 p.

MAUAD, M.; CRUSCIOL, C. A. C.; GRASSI FILHO, H. Produção de massa seca e nutrição de cultivares de arroz de terras altas sob condição de déficit hídrico e adubação silicatada. Semina: Ciências Agrárias, Londrina, v. 32, n. 3, p. 939-948, 2011.

MAUAD, M.; GRASSI FILHO, H.; CRUSCIOL, C. A. C.; CORREAA, J. C. Teores de silício no solo e na planta de arroz de terras altas com diferentes doses de adubação silicatada e nitrogenada. Revista Brasileira de Ciência do Solo, Viçosa, v. 27, n. 5, p. 867-873, 2003.

MITANI, K.; MA, J. F. Uptake system of silicon in different plant species. Journal of Experimental Botany, Oxford, v. 56, n. 414, p. 1255-1261, 2005.

MOTOMURA, H.; MITA, N.; SUZUKI, M. Silica accumulation in long-lived leaves of Sasa veitchii (Carriére) rehder (Poaceae-Bambusoideae). Annals of Botany, Oxford, v. 90, n. 1, p. 149-152, 2002.

OLIVEIRA, L.A.; ABREU JUNIOR, C. H.; CARNEIRO, J. M. T.; BENDASSOLLI, J. A. Mecanismo de absorção de silício pelas plantas. In: SIMPOSIO BRASILEIRO SOBRE SILÍCIO NA AGRICULTURA, 5., 2010, Viçosa, MG. Anais... Viçosa: Universidade Federal de Viçosa, 2010. p. 61-87.

PRABHU, A. S.; SANTOS, A. B.; DIDONET, A. D. Soluble tissue sugar content and leaf blast severity in response to the application of calcinated serpentinite as a silicon source in irrigated rice. Summa Phytopathology, Botucatu, v. 33, n. 4, p. 402-404, 2007.

RAIJ, B. van; ANDRADE, J. C.; CANTARELLA, H.; QUAGGIO, J. A. Análise química para avaliação da fertilidade dos solos tropicais. Campinas: Instituto Agronômica, 2001. 284 p.

RAIJ, B. van; CANTARELLA, H.; QUAGGIO, J. A.; FURLANI, A. M. C. Recomendações de adubação e calagem para o estado de São Paulo. 2. ed. Campinas: Instituto Agronômica, Fundação IAC, 1996. 285 p.
RAMOS, L. A.; KORNDORFER, G. H.; NOLLA, A. Acúmulo de silício em plantas de arroz do ecossistema. Bragantina, Campinas, v. 67, n. 3, p. 751-757, 2008.

RAVEN, J. A. Cycling silicon-the role of accumulation in plant. New Phytologist, Lancaster, v. 158, n. 3, p. 419421, 2003.

REZENDE, D. C.; RODRIGUES, F. A.; CARRÉMISSIO, V.; SCHURT, D. A.; SCHURT, D. A.; KAWAMURA, I. K. Effect of root and foliar applications of silicon on Brow spot development in rice. Australian Plant Pathology, Callingwood, v. 38, n. 1, p. 67-73, 2009.

SANTOS, A. B.; STONE, L. F.; VIEIRA, N. R. A. A cultura do arroz no Brasil. 2. ed. Santo Antônio de Goiás: Embrapa Arroz e Feijão, 2006. 1000 p.

SÁVIO, F. L.; SILVA, G. C. da; TEIXEIRA, I. T.; BORÉM, A. Produção de biomassa e conteúdo de silício em gramíneas forrageiras sob diferentes fontes de silicato. Semina: Ciências Agrárias, Londrina, v. 32, n. 1, p. 103-110, 2011.

TAIZ, L.; ZEIGER, E. Fisiologia vegetal. 4. ed. Porto Alegre: Artmed, 2009.

TAMAI, K.; MA, J. F. Characterization of silicon uptake by rice roots. New Phytologist, Lancaster, v. 158, n. 3, p.431-436, 2003.

TOKURA, A. M.; FURTINI NETO, A. E.; CARNEIRO, L. F.; CURI, N.; SANTOS, J. Z. L.; ALOVISI, A. A. Dinâmica das formas de fósforo em solos de textura e mineralogia contrastantes cultivados com arroz. Acta Scientiarum, Agronomy, Maringa, v. 33, n. 1, p. 171-179, 2011.

Van der VORM, P. D. J. Uptake of Si by five plant species, as influenced by variations in Si-supply. Plant and Soil, Netherlands, v. 56, n. 1, p. 153-156, 1980.

WINSLOW, M. D. Silicon, disease resistance, and yield of rice genotypes under upland cultural conditions. Crop Science, Madison, v. 32, n. 5, p. 1208-1213, 1992.

YAMAJI, N.; MA, J. F. Spatial distribution and temporal variation of the rice silicon transporter Lsi1. Plant Physiology, Waterbury, v. 143, n. 3, p. 1306-1313, 2007. 